\title{
CITIES AND REGIONS IN THE NEW LEARNING ECONOMY
}

\author{
Városok és régiók az új tudásalapú gazdaságban \\ (Organisation for Economic Co-operation and Development 2001., \\ Education \& Skills, vol. 2001, no. 2., 143 o.)
}

\section{HEGYI BARBARA}

Az innováció terjedésének gazdasági teljesítményre gyakorolt hatását a kilencvenes évek eleje óta számos felmérés kapcsán vizsgálta az OECD. Kutatási eredményeik bizonyították, hogy azok a cégek, amelyek folyamatos innovatív tevékenységet végeznek, sokkal kevésbé kiszolgáltatottak a gazdaság ciklikus ingadozásainak, de az első felmérések még nem tudták kimutatni az innováció közvetlen hatását a gazdasági teljesítményre.

Az ezredfordulót követően azonban az OECD az innovációt mint a társadalmi fejlödés és a gazdasági versenyképesség kulcsfontosságú tényezőjét kezdte elemezi. Számos tanulmány született az innováció oktatási szemléletváltásra gyakorolt hatásáról, a jövőbeli, innovatív struktúrákra épülö képzési rendszerek potenciális konfliktusairól a lassan változó bürokratikus irányítással szemben. A szabadalmak, az innováció és a gazdasági növekedés összefüggéseit az OECD folyamatosan elemzi a vállalkozások, a nagy iparvállalatok és a helyi döntéshozók szemszögéből is.

A jelen ismertetőben bemutatott publikáció a városok és régiók új szerepei - helyi szintủ tanulás, innováció és gazdasági teljesítmény növekedésének elősegítése kapcsán vizsgálják a kormányzás területén megjelenő új kihívásokat. A könyv hét fejezetben elemzi a tanulás különböző formái és a regionális gazdasági teljesítmény közti összefüggéseket, és rávilágít az egyéni és a szervezeti tanulás gazdasági teljesítményben betöltött szerepére. A kiválasztott öt régió és város esettanulmányai a társadalmi tôke egyéni és szervezeti tanulásra gyakorolt hatását is bemutatják, valamint megismerhetjuik az új tudásalapú városok és régiók létrehozásához ajánlott OECD irányelveket.

$\mathrm{Az}$ első fejezet az új, tudásalapú gazdaságot („,knowledge-based or learning economy", 11. o.) regionális tudásalapú gazdaságok és városok müködésének példáin keresztuil definiálja. A tudásalapú régió vizsgálatának koncepcionális kereteit a második fejezet teremti meg az innovációs rendszerek, az egyéni és szervezeti tanulás modelljei, valamint a gazdasági teljesítmény fogalomrendszerének ismertetésével. Az empirikus vizsgálat kutatási kérdéseit a harmadik fejezet vázolja fel (31-33. o.).

A negyedik fejezet részletesen ismerteti az empirikus kutatás eredményeit, az egyéni, a szervezeti tanulás, társadalmi együttmúködés és ezek regionális gazdasági teljesítményre gyakorolt hatása vonatkozásában. 
Tér és Társadalom 20. évf. 2006/4. 183-206. p.

Az egyéni tanulás és gazdasági teljesítmény (35-41. o.) viszonyában az elemzés tisztán kimutatja az összefüggést a képzettség megszerzése és a gazdasági növekedés regionális szintje között. A vizsgálat eredménye alapján 180 régióban a középfokú képzettség megszerzése nagyobb mértékben befolyásolja a gazdasági teljesítményt, és ez alátámasztja azt a tényt, hogy a gazdasági teljesítmény egy jelentős hányada a szervezeti rutinok zavartalan müködésén múlik. Ettől függetlenül a felsöoktatást természetesen nagyon fontos tényezőként kezeli, föként az innovatív képességek terén, ám ez a következetés módosul a különböző nemzeti variációk tükrében. Például a korábbi Nyugat-Németország vagy az Egyesült Királyság területén a felsőfokú oktatás az, amely a legnagyobb hatással bír a gazdasági teljesítményre. Ezért létfontosságú, hogy az egyes képzések megszerzésének különbözö szintekre gyakorolt hatásai összekapcsolódjanak az adott ország gazdasági struktúrájával ugyanúgy, mint nemzeti politikai és intézményi hagyományokkal. Ehhez hasonlóan regionális szinten is kulcsszerepe van a szervezeti struktúráknak és regionális intézményeknek az oktatás és a gazdasági teljesítmény összehangolásában. A régi struktúrák jelentős korlátozó hatást gyakorolhatnak a regionális gazdasági teljesítményre, hacsak nem jön létre egy olyan új képzési rendszer, amely a régió ipari szerkezetéhez és foglalkoztatási struktúrájához jól illeszkedik.

Általánosságban a korrelációs elemzés viszonylag erős összefüggést mutat ki $a$ szervezeti tanulás (amelyet az 1 millió lakosra jutó szabadalom bejelentések és az egy före jutó $\mathrm{K}+\mathrm{F}$ kiadások mutatóin keresztül jellemez a felmérés) és a gazdasági teljesítmény (1 före jutó GDP) között (4l-46. o.). A fejezetben felvetödik a kérdés, hogy vajon a szervezeti tanulás ( $\mathrm{K}+\mathrm{F}$ és szabadalmak) gazdasági teljesítményre gyakorolt hatását kell-e vizsgálni vagy fordítva. Különösen nehéz az ok-okozati összefüggés feltárása, mivel mindkét értelmezés kézenfekvő. Az innovatív cégek nagy mértékben hozzájárulnak a jobb gazdasági teljesítmény eléréséhez, és ezáltal az erős regionális szintủ szervezeti tanulás révén fokozottabb gazdasági eredmények érhetók el. Alternatívaképpen, a cégek számára jövedelmezö lehet többet fektetni a K+F-be, amelynek révén még több forrás vonható be, és egyre több szabadalmaztatott innovatív termékkel és szolgáltatással jelennek meg a piacon. Ez egy állandó körfolyamatot eredményez: a gazdasági teljesítmény növekedése több $\mathrm{K}+\mathrm{F}$ kiadást tesz lehetővé, amely egyre több szabadalmat implikál, amely még jobb gazdasági teljesítményhez vezet, amely még több $\mathrm{K}+\mathrm{F}$ kiadást tesz lehetővé és így tovább. Az összefüggés vizsgálata azzal zárul, hogy ebben az esetben egy sokkal inkább részletes bizonyítási folyamatra lenne szükség, hogy nagy biztonsággal megállapítható legyen, hogy a $\mathrm{K}+\mathrm{F}$ kiadások és a szabadalmaztatott innovációs formák (mint a szervezeti tanulás egyéb formái) pontosan miként implikálnak regionális gazdasági fejlődést.

Az empirikus kutatások eredményei a képzettség megszerzése és a szabadalmi intenzitás közötti összefüggés kapcsán igazolták a kutatók a kezdeti elvárásait az egyéni tanulás szervezeti tanulásra gyakorolt hatásának vonatkozásában (46-49. o.). A felsőfokú képzettség megszerzésének hatása ebben az összefüggésben került a leginkább kimutatásra: a viszonylag gyenge, de pozitív korreláció jelzi, hogy milyen nélkülözhetetlen szerepet tölthet be a felsöoktatás a szervezeti tanulásban és az innovációban. 
Természetesen ebben az esetben is fontos figyelembe venni, hogy a különböző régiók divergens társadalmi és gazdasági adottságai más-más hatásokat eredményeznek.

A fejezetben bemutatott empirikus vizsgálat a tanulás és társadalmi együttmüködés (49-51. o.) közti összefüggést vizsgálta utolsóként. Az egyéni tanulás, mint középfokú végzettség megszerzése és a munkanélküliség közti kapcsolat negatív korrelációt mutatott. Megállapították, hogy az egyéni tanulás csökkenti a társadalmi kirekesztödés mértékét, de a korreláció gyenge. Az e két változó közti korrelációs analízis kevésbé volt eredményes, mint az elözö három összefüggés esetében, ezért a kutatók további empirikus vizsgálatot ítélnek szuikségesnek e bonyolult tézis vizsgálatához.

A korrelációs analízisben alkalmazott indikátorokat és a vizsgált összefüggéseket a 4.1.-es függelék összesíti (52-53. o.).

Az ötödik fejezetben bemutatott esettanulmányokban szereplö öt régió mindegyike a tudásalapú régí́ „vízióját” választotta, ennek megfelelő helyi politikákat alakítottak ki; habár mind egy-egy EU tagállamban helyezkednek el, egészen más társadalmi-gazdasági kondíciókkal rendelkeznek, így a tanulságok nagymértékben különböznek egymástól.

Jéna (Németország) érdekes példája a politikai tanulási folyamatok, az oktatás területén meglévő széleskörú erőfeszítések, az egyetemi kutatások és ipari szolgáltatások által ösztönzött a mélyreható ipari szerkezetváltásnak (56-64. o.).

Jéna politikai döntéshozói számára óriási volt a kihívás, ezért eröfeszítéseiket kevés számú területre tudták csak összpontosítani. Az elemzés kitér arra, hogy számos helyi szintủ kritika érte őket, amiért az ipari szerkezetváltás túlságosan egyoldalú és csak nagyon kis mértékben diverzifikált, a szerves, alulról felfele jövỏ tanulási folyamatokat visszaszorították. A munkavállalói részvétel és a társadalmi töke alacsony szintje a fenti helyzetet súlyosbították. Habár elindultak a cégek közötti hálózatok fokozatos kialakítására és a decentralizációra irányuló kezdeményezések, Jéna társadalmi tőkéje csak lassan indult növekedésnek. Az elemzök szerint, ha az ipari szerkezetváltás és a társadalmi tőkébe való befektetés mellett Jénának sikerül megöriznie fontos tudásbeli tökéjét es "'állalkozási kultúráját, akkor Jéna tanulási kapacitása folyamatosan növekedni fog.

A Vienne-röl (Franciaország) szóló esettanulmány betekintést enged egy olyan regionális gazdaságba, amely az elmúlt 15 évben drámai átalakuláson ment keresztül (64-70. o). Ezt a fejlődést felülről lefele irányuló politika vezérelte, amely egyetlen projektre koncentrált, nagyon következetesen. Egyrészröl a Futuroscope szabadidőpark nagyon pozitív imázst sugároz a régiónak, ezáltal vonzza a turistákat és hozzájárul egy szolgáltatás-alapú gazdaság fejlődéséhez. Másrészről pedig megpróbálták összehozni az akadémiai és az ipari kutatást annak érdekében, hogy fokozza az egyéni tanuláshoz szükséges általános adottságokat és növelje a „technológiai müveltséget"(technological literacy 70. o). Ha a helyi döntéshozók kezdetben azt is remélték, hogy a második elem lesz a legfontosabb a regionális fejlödésben, az első ehelyett sokkal inkább sikeresnek bizonyult. Vienne számára az elemzők szerint a legnagyobb kockázatot az jelentheti, hogy a helyi döntéshozói megfeledkeznek kezdeti hosszú távú céljaikról, és megelégednek a rövid távú eredményekkel, 
nevezetesen az új turisztikai attrakcióval. Vienne tehát egy olyan kockázatot mutat be, amelyet a regionális tanulás politikájának egyetlen projektre történő alapozása jelenthet. A technológiai parkja még nem generált megfelelő számú szakmai alapokra épủlő hálózatot a régióban, és nem vonzott nagy cégeket az ICT (Information Communication Technology) szektorba. A cégek közötti hálózatok kialakulását akadályozhatja a tiszta regionális specializáció hiánya (amely a turizmustól elkülönülö), valamint a társadalmi töke hiánya a menedzserek cégközi kapcsolatokat érintő koordinációjában. Az a néhány szakmai hálózat, amely a Futuroscope projekt kapcsán létrejött, csakis a szabadidőpark müködésének köszönető. Van azonban egy paradoxon: a legfontosabb „high-tech” cégek, amelyek oda tudnák vonzani a többi nagy céget is, és ezáltal növekedne a regionális gazdaság teljesítménye, hiányoznak Vienne-böl, és ez a domináns technológiai klaszter, az Il-de-France közelségének tulajdonítható.

Nagy valószínüséggel a Futorscope kapcsán a regionális identitás megerősödik, és ezáltal a projekt fejleszti a társadalmi tőkét és az innovációt a jövőben. A felmérés eredményei azt tükrözik, hogy Vienne egy átmeneti pozíciót foglal el: döntően már megváltoztatta eddigi gazdasági tevékenységének jellemzőit, de még nem talált újakat helyettük.

Øresund (Dánia/Svédország) ${ }^{\lfloor}$egy olyan prosperáló regionális innovációs rendszer, amely magában foglalja mind a „high-tech”, mind pedig „low-tech” iparágakat (70-77. o). Fontos példája azoknak az elérhető regionális hasznoknak, amelyeket a szervezeti tanulás és a gazdasági teljesítmény hatékony koordinációja, az egyéni tanulás (mind közép, mind pedig felőfokú szinten) és az egyetemi kutatások elösegítése, valamint a megfelelö regionális iparszerkezet tesz lehetővé.

A jelenleg futó regionális projekt többet jelent, mint egy létező régió: Øresund számos olyan problémába enged betekintést, amelyeket a régió épités és integráció nehézségei jelentenek. Øresund kiváló példa arra, hogy milyen nagy szerepe van a civil társadalmi tökének a politikai tanulási folyamatokban, de arra is példaként szolgál, hogy szükséges befektetni a menedzserek között kialakítandó hálózatokba, mind pedig a társadalmi tőkébe, ha az integráció magasabb foka és a gazdasági hasznok érhetők el ezáltal.

A civil, szakmai és cégek közötti hálózatok kialakítása az egész Øresund régión keresztül nagyon bonyolult politikai feladatnak bizonyult, mivel a meglévő hálózatok és konvenciók antagonisztikusnak bizonyultak. Mivel a hálózatépítés egy társadalmi folyamat, és ezáltal legalább annyira a társadalmi tőkén, mint az infrastruktúrán alapszik, a nagymértékü felülröl-lefele jövő infrastrukturális befektetés eddig nem bizonyult elégségesnek az integráció elösegítéséhez. A felmérések eredményei szerint mind az oktatás, mind pedig a tömegmédia társadalmi tőke erősítésébe való bevonása a jövőbeli politikai döntéshozatal központi eleme kell, hogy legyen.

Andalúzia (Spanyolország) ipari szektorai és cégei viszonylag elszigetelten müködnek egymástól, és nagyon kevés állami, magán vagy civil szervezet kötődik hozzájuk (77-82. o.). A tanulmányban bemutatott Andalucía Innovation Network a legnagyobb ipari szereplők együttmüködési hajlandóságát, az ezek kapcsán létrejövő 
kooperációt igyekszik erősíteni; ugyanis az andalúz regionális intézmények és az ilyen exkluzív partnerségek között egy mély szervezeti szakadék húzódik.

A régió politikai vezetése egyre több intézkedést tesz annak érdekében, hogy nagyobb figyelem irányuljon a tanulási folyamatokra és a társadalmi változásokra, de nagyon sok szervezeti és intézményi kezdeményezésnek még meg kell erösödnie; amelyhez képzési erőforrások magasabb szintü koordinácioja, az állami $\mathrm{K}+\mathrm{F}$ támogatások növelése, ipari szolgáltatások biztosítása a meglévő ipari struktúrák fenntartásához, valamint tudásbázisok kiépítése szükséges. A társadalmi változásoknak pedig oly módon kell hozzájárulniuk egyre több szakmai és nem szakmai együttmúködés kialakulásához, hogy a meglévő regionális identitást és a turizmusban jelenleg is fontos szerepet betöltő kulturális elemeket lerombolnák.

Kent Thames-side (Nagy-Britannia) még az elözö négy esettanulmányhoz képest is különösen újszerü vállalkozás (83-92. o.), amely Anglia délkeleti részét és Kent county magas népességszámú, nagyrészt városi területekböl álló vidékeit foglalja magába. Kent Thames-side nem adminisztratív értelemben vett régió: egy olyan poszt-indusztriális terület, amely a történelmi iparainak összeomlása után az aktív gazdasági szerepvállalás új lehetőségeit kutatja. Kent Thames-side az elemzök szerint nagyon jó példa a politikai szerepvállalás fontosságára és a nagyszabású projektek jelentőségére a helyi motivációk megváltoztatásában, a public-private-partnershipek számának növekedésében, azok társadalmi töke erösítésében betöltött szerepére.

Mennyire tudja Kent-Thames side befolyásolni a helyi identitás kialakulását egy olyan heterogén környezetben, amely különbözö városokból és közösségekböl áll, és nagyon kevés közös töténelemmel rendelkezik? Mennyire sikerül egy egyéni és szervezeti tanulásban bővelkedő régiót kialakítani? A kutatók szerint Kent Thamesside kísérlet sikere a területre visszatelepülö helyi gazdaság minden szinten jelenlévő koordinációján és a poltikai vezetés oktatási és képzési ügyekre fordított figyelmén, valamint a társadalmi együttmüködési hajlandóságon múlik.

Az esettanulmányok alapjául szolgáló szakirodalmat, valamint az elemzések módszertani következtetéseit az 5.1. számú fiiggelék (93. o.) mutatja be.

A „tudásalapú régió" (Towards the „learning region”, 95. o.) irányába történő elmozdulást igazoló empirikus következtetéseket a hatodik fejezet összegzi (95111. o.). Az OECD tanulmány jelen fejezete számos olyan állítást ismertet, amelyek a tanulás és gazdasági teljesítmény közti összefüggés viszonyának vizsgálatában kiemelkedö jelentöséggel bírnak: bár az egyéni tanulás önmagában nem értelmezhetó, de az ezáltal megszerzett tudás cégeknél, szervezeteknél történö alkalmazása hozzájárul a regionális fejlődéshez, ezáltal a gazdasági teljesítményhez. Megállapítást nyert az a tény is, hogy növekedést indukáló cégek nem feltétlenül hightech cégek, és azok a képességek, amelyek hozzájárulnak a szervezeti tanulás folyamatához, leginkább a középiskolai oktatásban és nem a felsőfokú oktatásban szerezhetök meg. A szervezeti tanulás sokkal inkább hozzájárul a gazdasági hatékonyság növekedéséhez, mint a szabadalmakból származó eredmények: ugyanis folyamatok és a termékek munka közben megismerhetök és elsajátíthatók (, learning by doing”), és a járulékos tanulás legalább annyira biztosítja a verseny- 
képességet, mint a szabadalmi jogok. Ha a regionális gazdaság teljesítménye a tanuláson alapszik, egyéni, szervezeti és regionális szinten a koordináció nélkülözhetetlen. Azok az együttműködések, amelyek állami és magánhálózatokat kapcsolnak össze, nemcsak a forrászerzésben (fund raising) töltenek be fontos szerepet, hanem a regionális gazdaság elemeinek koordinációjában is. A politikai döntéshozóknak a regionális tanulás politikájának fejlesztésében nagyon finom egyensúlyt kell találniuk az összpontosító, intervencionista, szervezeti és intézményi tervezés és támogatás területén, amely lehetövé teszi az alulról jövö kezdeményezések kibontakozását.

A könyv utolsó, hetedik fejezete (113-121. o.) a tudásalapú városok és régiók létrehozásának politikai elveit tartalmazza, amelyek tulajdonképpen az OECD e területre vonatkozó ajánlásainak is tekinthetök.

A gazdasági teljesítményük fejlesztését innováció-intenzív tevékenységekre alapozó városok és régiók, illetve azok helyi döntéshozói számára ajánlott legfontosabb politikai elvek az alábbiak:

- Azon magas szintủ és erőforrásokkal jól alátámasztott oktatási intézkedésnek a megléte az adott területen, amelyek révén a hatékony egyéni tanulás lehetséges, és amelynek eredményeképpen az emberek életszínvonala emelkedhet, nélkülözhetetlen. A társadalmi tőke folyamatos fejlesztése a hatékony szervezeti tanulás és innováció elösegítésének alapfeltétele

- A regionális gazdaságban a képzett és képezhető személyek keresletének és kínálatának finom összehangolása az oktatáson keresztül munkaerőpiaci egyensúlyt eredményez, de figyelmet kell fordítani arra, hogy az egyéni tanulás haszna megjelenjen a szervezeti tanulásban is.

- Az interaktív hálózatokon keresztül szükség van megfelelő keretek kialakítására a szervezeti tanulás fejlesztéséhez, mind az egyes cégeken belül, mind pedig a cégek és más szervezetek között, és az elért eredmények folyamatos visszacsatolása a cégek felé további inspirációkat adhat a tanuláshoz.

- Elengedhetetlen a hatékony szervezeti tanulás megkönnyítése nemcsak a konvencionálisan innovatív high-tech cégek körében, hanem minden olyan ipari és szolgáltatási ágban és szervezetnél is, amelyeknek van lehetöségük az innovatív kapacitásuk fejlesztésére.

- Nagy hangsúlyt kell fektetni azoknak a tényezőknek az óvatos beazonosítására az adott régióban, amelyek a gazdasági fejlődést akadályozhatják (pl. meglévő iparágak, oktatási intézkedések, kutatási adottságok stb.), illetve azoknak a tényezöknek a számbavételére, amelyek hasznosíthatók a jövöbeli innovatív stratégiák kialakításában

- Nagy figyelmet kell fordítani a koordinációs politikák mechanizmusaira az ágazati felelősségek különválasztásánál (ipari fejlesztés, $\mathrm{K}+\mathrm{F}$, tudomány és technológia, képzés és oktatás stb) és a különbözö szintekre történö elosztásánál (regionális, nemzeti és szupranacionális). 
A kiadványban bemutatott, tudásalapú fejlesztésekre berendezkedett régiók és városok különbözö társadalmi, gazdasági adottságokkal rendelkeznek, így innovációra alapozott szerkezetváltásaikat is eltérö ütemben és eredményekkel tudták megvalósítani. Az ismertetett projektek legfontosabb közös vonása az, hogy a városok és régiók mindegyike a tudásalapú fejlesztéseket kulcsfontosságú tényezönek tekinti hosszú távú versenyképessége és gazdasági teljesítményének növelése szempontjából. Bár a sikeres, tudásalapú városok és régiók létrehozásához nem lehet egységes, mindenkire érvényes, „receptet” alkotni, a kötetben bemutatott együttmüködések, fejlesztések tapasztalatai és az ezekre alapozott politikai ajánlások hasznosak lehetnek a magyar helyi fejlesztési koncepciók, stratégiák kidolgozásában is.

\section{Jegyzet}

1 Øresund egy tengerszoros, amely elválasztja Dániát és Svédországot. A két tengerparti mélyföldi területnek hosszú közös történelme van, azonban a nemzeti határaik 1658 óta kettéválasztották öket. A 2000 júliusában átadott Øresund híd ismết összeköti a két területet, amely ezáltal egy új EU régiót képez, és amit szintén Øresund-nak neveztek el (www.mva.org/composite-941.htm). 
Tér és Társadalom 20. évf. 2006/4. 183-206. p.

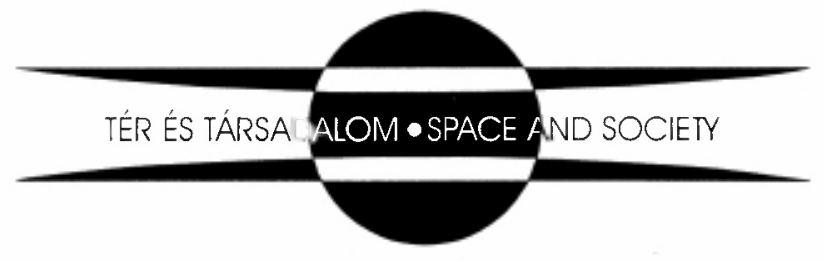

